Pacific Journal of Mathematics

ON SETS REPRESENTED BY THE SAME FORMULA IN
DISTINCT CONSISTENT AXIOMATIZABLE ROSSER

Robert ARNoLd Di PAOL 


\title{
ON SETS REPRESENTED BY THE SAME FORMULA IN DISTINCT CONSISTENT AXIOMATIZABLE ROSSER THEORIES
}

\author{
RoBert A. DiPaOla
}

\begin{abstract}
In this note a theorem is proved which includes the following: if $T$ is a consistent, axiomatizable Rosser theory in which all recursive functions of one argument are definable and $S$ is any sentence undecidable in $T$, then given any pair $\left(d_{1}, d_{2}\right)$ of $r e$ (recursively enumerable) degrees, there is a formula $F$ which represents a set of degree $d_{1}$ in $T$ and of degree $d_{2}$ in $T^{\prime}=T(S)$, the theory obtained from $T$ by adjoining $S$ as a new axiom.
\end{abstract}

For the theory of recursive functions, we follow [1]. If $T$ is a theory and $S$ a sentence undecidable in $T$, we write $T(S)$ for the theory obtained by adding $S$ to $T$ as a new axiom.

THEOREM. If $T$ is a consistent, axiomatizable theory in which all recursive functions of one argument are definable, and in which some EI (effectively inseparable) pair of re sets is separable, and $S$ is any sentence undecidable in $T$, then if $(A, B)$ is any pair of re sets with $A \subset R \subset B$, where $R$ is recursive, there is a formula which represents $A$ in $T$ and $B$ in $T(S)$.

Proof. The quite simple proof proceeds by way of two lemmas.

Lemma 1. If $T$ and $S$ are as in the theorem, $A$ is an re set and $R$ is a recursive subset of $A$, there is a formula which represents $R$ in $T$ and $A$ in $T(S)$.

Proof. We take formulas $F(x)$ and $G(x)$ such that $F(x)$ represents $A$ in $T(S)$ and $G$ defines $R$ in $T$ and hence in $T(S)$. The formula $H(x)=(F(x) \wedge S) \vee G(x)$ represents $R$ in $T$ and $A$ in $T(S)$.

Lemma 2. If $T$ and $S$ are as above and $A$ is any re set, there is a formula which represents $A$ in $T$ and the set $I$ of nonnegative integers in $T(S)$.

Proof. Consider an re EI pair $\left(U_{1}, U_{2}\right)$ and a formula $F(x)$ which separates $\left(U_{1}, U_{2}\right)$ in $T$. The formula $F(x) \vee S$ represents $I$ in $T(S)$; it represents in $T$ a superset of $U_{1}$ disjoint from $U_{2}$, and consequently represents a creative set $C$ in $T$. Using a well-known theorem of Myhill, 
we take a recursive function $f$ such that $A=f^{-1}(C)$. Using an argument similar to that of Lemma 1 of [2], we can find a formula $G(X)$ which represents $A=f^{-1}(C)$ in $T$ and $I=f^{-1}(I)$ in $T(S)$. The lemma is proved.

To complete the proof of the theorem, we take $F(x)$ representing $A$ in $T$ and the set $I$ in $T(S)$, by Lemma 2 , and $G(x)$ representing $R$ in $T$ and $B$ in $T(S)$. The formula $H(x)=F(x) \wedge G(x)$ represents $A$ in $T$ and $B$ in $T(S)$.

If $\left(d_{1}, d_{2}\right)$ is any pair of re degrees, we can find re sets $A$ and $B$, with $A \subset R \subset B$, where $R$ is recursive, such that $A$ is of degree $d_{1}$ and $B$ of degree $d_{2}$. We consequently have:

COROLlary. If $T$ and $S$ are as in the theorem and $\left(d_{1}, d_{2}\right)$ is any pair of re degrees, there is a formula $F$ which represents a set of degree $d_{1}$ in $T$ and of degree $d_{2}$ in $T(S)$.

Thus, with regard to the consequences of adding sentences $S$ undecidable in a theory $T$ as new axioms, we see that one undecidable sentence is as good as another insofar as representation of sets of distinct degree of unsolvability by the same formula is concerned.

\section{REFERENCES}

1. M. Davis, Computability and Unsolvability, McGraw Hill, 1958.

2. H. Putnam and R. Smullyan, Exact separation of recursively enumerable sets within theories, Proc. Amer. Math. Soc. 11 (1960), 574-577.

Received September 14, 1965. The preparation of this paper was sponsored by the Office of Naval Research. Reproduction in whole or in part is permitted for any purpose of the United States Government.

University of California, Los ANgeles 


\section{PACIFIC JOURNAL OF MATHEMATICS}

\section{EDITORS}

\author{
H. SAMELSON, \\ Stanford University \\ Stanford, California \\ R. M. BLUMENTHAL \\ University of Washington \\ Seattle, Washington 98105
}

\author{
*J. DugundJI \\ University of Southern California \\ Los Angeles, California 90007 \\ RICHARD ARENS \\ University of California \\ Los Angeles, California 90024
}

\section{ASSOCIATE EDITORS}
E. F. BECKENBACH
B. H. NeUmanN
F. WOLF
K. YOSIDA

\section{SUPPORTING INSTITUTIONS}

\author{
UNIVERSITY OF BRITISH COLUMBIA \\ CALIFORNIA INSTITUTE OF TECHNOLOGY \\ UNIVERSITY OF CALIFORNIA \\ MONTANA STATE UNIVERSITY \\ UNIVERSITY OF NEVADA \\ NEW MEXICO STATE UNIVERSITY \\ OREGON STATE UNIVERSITY \\ UNIVERSITY OF OREGON \\ OSAKA UNIVERSITY \\ UNIVERSITY OF SOUTHERN CALIFORNIA
}

\author{
STANFORD UNIVERSITY \\ UNIVERSITY OF TOKYO \\ UNIVERSITY OF UTAH \\ WASHINGTON STATE UNIVERSITY \\ UNIVERSITY OF WASHINGTON \\ * * * \\ AMERICAN MATHEMATICAL SOCIETY \\ CHEVRON RESEARCH CORPORATION \\ TRW SYSTEMS \\ NAVAL ORDNANCE TEST STATION
}

Mathematical papers intended for publication in the Pacific Journal of Mathematics should be typewritten (double spaced). The first paragraph or two must be capable of being used separately as a synopsis of the entire paper. It should not contain references to the bibliography. Manuscripts may be sent to any one of the four editors. All other communications to the editors should be addressed to the managing editor, Richard Arens at the University of California, Los Angeles, California 90024 .

50 reprints per author of each article are furnished free of charge; additional copies may be obtained at cost in multiples of 50 .

The Pacific Journal of Mathematics is published monthly. Effective with Volume 16 the price per volume (3 numbers) is $\$ 8.00$; single issues, $\$ 3.00$. Special price for current issues to individual faculty members of supporting institutions and to individual members of the American Mathematical Society: $\$ 4.00$ per volume; single issues $\$ 1.50$. Back numbers are available.

Subscriptions, orders for back numbers, and changes of address should be sent to Pacific Journal of Mathematics, 103 Highland Boulevard, Berkeley 8, California.

Printed at Kokusai Bunken Insatsusha (International Academic Printing Co., Ltd.), No. 6, 2-chome, Fujimi-cho, Chiyoda-ku, Tokyo, Japan.

PUBLISHED BY PACIFIC JOURNAL OF MATHEMATICS, A NON-PROFIT CORPORATION

The Supporting Institutions listed above contribute to the cost of publication of this Journal, but they are not owners or publishers and have no responsibility for its content or policies.

* Paul A. White, Acting Editor until J. Dugundji returns. 


\section{Pacific Journal of Mathematics}

\section{Vol. 18, No. 3 \\ May, 1966}

William George Bade and Philip C. Curtis, Jr., Embedding theorems for commutative Banach algebras .......................... 391

Wilfred Eaton Barnes, On the $\Gamma$-rings of Nobusawa ................. 411

J. D. Brooks, Second order dissipative operators ................ 423

Selwyn Ross Caradus, Operators with finite ascent and descent ........ 437

Earl A. Coddington and Anton Zettl, Hermitian and anti-hermitian properties of Green's matrices .......................... 451

Robert Arnold Di Paola, On sets represented by the same formula in distinct consistent axiomatizable Rosser theories ................... 455

Mary Rodriguez Embry, Conditions implying normality in Hilbert space ...........................................

Garth Ian Gaudry, Quasimeasures and operators commuting with convolution ................................... 461

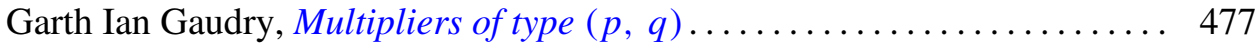

Ernest Lyle Griffin, Jr., Everywhere defined linear transformations affiliated with rings of operators .................................. 489

Philip Hartman, On the bounded slope condition ................ 495

David Wilson Henderson, Relative general position ................ 513

William Branham Jones, Duality and types of completeness in locally

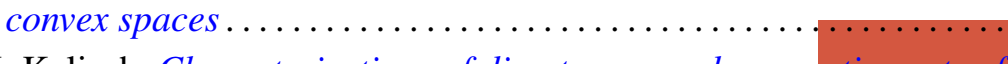

G. K. Kalisch, Characterizations of direct sums and commuting sets of Volterra operators....

Ottmar Loos, Über eine Beziehung zwischen Malcev-Algebren und Lietripelsystemen

Ronson Joseph Warne, A class of bisimple inverse semigroups . . . 